\title{
On Efficient Causation for Homosexual Behaviours among Traditional Africans: An Exploration of the Traditional Yoruba Model
}

\author{
Dasaolu, Babajide Olugbenga \\ Department of Philosophy, \\ Olabisi Onabanjo University, \\ Ogun State, Nigeria. \\ Email: dasaolu.babajide@yahoomail.com
}

\begin{abstract}
In the face of the recent backlashes against homosexual persons in Africa, on the ground that the phenomenon is un-African and/or threat to procreation and marital values, it is pertinent to review the discourse in the light of how ancient Africans perceived the reality. This is imperative given the lack of consensus on the part of scientists to disinter a conclusive finding on what causes homosexual behaviours among humans. In this research, I employ traditional Yorùbá philosophy to provide a plausible justification for homosexuality among the people. In the face of this justification via Yorùbá folklore, I find that there is no documented evidence among the ancient Yorùbá that is suggestive of discrimination and stigmatization of homosexuals and inter-sex persons. As homosexual persons were respected but not criminalized, this study recommends the regurgitation of this outlook in the contemporaneous dealings with homosexual persons, beginning with the repealing of the Same-Sex Marriage Prohibition Act of 2014 in Nigeria, which is inconsistent with African values and outlooks on the subject.
\end{abstract}

Keywords: Homosexuality; Philosophy; Causal Factor; Yorùbá Folklore; Africa

Introduction: What causes homosexual behaviours among humans? Is there any conclusive scientific evidence for homosexual orientations? These are the questions that initiated this research in the first place. Upon a critical scrutiny of some of the foremost claims on the causative factors for homosexual behaviours, it is unfortunate that there is nothing conclusive or suggestive of clinical validation. The matter is unfortunate because homosexual persons have been perceived as less than normal humans. In some countries, they are even persecuted for being who they are. But must this continue? If there are no scientific validations, the cause of homosexual behaviours, is it possible to employ a traditional African outlook to examine the phenomenon for solace? How relevant and penetrating, the African position on the cause of homosexual behaviours? Furthermore, were homosexual persons in traditional Africa criminalized and stigmatized? These are the questions that I seek to explore within the pages that follow. I will end the inquiry with some thoughtful 
recommendations on how to deal with homosexuals in contemporaneous times.

The Quest for Efficient Causation for Homosexuality in the Sciences: The search for the cause of homosexual behaviours has put psychologists, genetic scientists, psychiatrists and even philosophers to work. For those who are affiliated to the study of genes, biologism has been put forward as an approach.

Biologism is "...the view that human behavior and social situations can be causally explained by an appeal to the physical mechanisms at play in the organic biological processes of the human body."1 The understanding here is that homosexuals have been determined by the genes and hormones in their bodies to have sexual orientations or affiliations as they do. In other words, they have been programed by genetics to be thus. Natalie Angier²; Christopher Daly ${ }^{3}$; Curt Suplee ${ }^{4}$ are few minds who have used media as a medium to publish these scientific findings. However, this perspective has come under scrutiny. The works of Stanton L. Jones and Don E. Workman $^{5}$ and Richard C. Friedman and Jenifer Downey ${ }^{6}$ have served sharply to show that there is no conclusive scientific judgment "that homosexual orientation or attraction (much less behaviour) is biologically fixed or immutable." ${ }^{7}$ In a related development, psychiatrists Richard C. Friedman and Jenifer Downey observe that:
"At clinical conferences one often hears discussants commenting that "homosexuality is genetic" and, therefore, that homosexual orientation is fixed and unmodifiable. Neither assertion is true... The assertion that homosexuality is genetic is so reductionistic that it must be dismissed out of hand as a general principle of psychology." 8

Other renowned minds that have made profound efforts to seek the what science claims to be the cause(s) of homosexual orientations in humans are: Simon LeVay'; William Byne and Bruce Parsons ${ }^{10}$; Simon Burton. ${ }^{11}$ The widespread accentuated but unfortunate outcome is that there is no proper scientific evidence to serve as effective causation for homosexual orientation in humans. Perhaps one may think that the lack of consensus among scientists, as it pertains to the causal factor of homosexual behaviours may be responsible for the malicious treatment and estrangement of homosexuals in several places in Africa, such an outlook lacks basis, especially when considers the scientific verdict on race and the endless discrimination on the basis skin colour.

After several years of stigmatization and discrimination against Africans and people with black skin, the scientific community has come to the conclusion that human genetic diversity cannot be captured by race. In the $21^{\text {st }}$ century, Francis Collins and Craig Venter, after extensive and rigorous 
laboratory efforts, conclude that human genetic diversity cannot be captured by the concept of race. They revealed as well that all humans have genome sequences that are $99.9 \%$ identical. $^{12}$ For Venter, the concept of race has no genetic or scientific basis. ${ }^{13}$ In the same vein, Collins and Mansoura chronicle: "those who wish to draw precise racial boundaries around certain groups will not be able to use science as a legitimate justification." ${ }^{\prime 14}$ It is the case that even when most of these scientific validations on race arrived at the turn of the millennium, there has been the continuous interest on segregation on the yardstick of skin colour. When one applies this sense of reasoning to homosexuality, the analogy will be too glaring to require further elaborations. As a result, homosexuals will likely continue to suffer stigmatization in the face of scientific explanation (assuming there is at least, one).

Furthermore, the presence or absence of a causative factor by scientists has not improved the situation of LGBQT in Africa since there has been the emphasis, mostly by African heads of government that homosexuality is "un-African, a disease of the morally corrupt West." 15 It is therefore pertinent, at this juncture to explore the popular response within Africa - rejection and stigmatization of homosexuals.

Homosexuality from the Mainstream and Dominant African Perspective: My task here is to explore and attempt a reconstruction of the vehemence against homosexual behaviours in Africa from the hands of her heads of government and scholars versed with the African past.

Despite the moral bankruptcy that has generally characterized leadership in Africa, it is interesting to note that most African leaders have denounced homosexuality as evil, unnatural and incongruent to African culture and psyche. A brief survey of some of their views is revealing: President Robert Mugabe of Zimbabwe compared homosexuality to bestiality and has ordered the Police to raid the offices of Gays and Lesbians. ${ }^{16}$ In fact, Mugabe claimed that homosexuals were "worse than pigs and dogs." 17 Namibian President, San Nujoma, was more antagonistic and vitriolic in his attack of the homosexuals. He declared that "the Republic of Namibia does not allow homosexuality or lesbianism here. Police are ordered to arrest you, deport you and imprison you."18 Nujoma sees homosexuality as against God's will and act that shows that the devil is at work. Indeed, Namibia's Home Affairs Minister, Jerry Ekandjo urged the Police officers to eliminate gays and lesbians from the face of Namibia. ${ }^{19}$

There are others beside those in the leadership cadre who feel that homosexuality is totally un-African and that it negates all the cherished values of a typical African. Thus the reactions of Africans may take the following forms: That homosexuality should not be accepted, it is 
not the plan of God...it is completely bad and it does not originate from Africa, it is satanic and controlled by the evil spirits. John Ernest is of the view that homosexuals should be disenfranchised in Africa; they have no rights to be respected. Ernest opined that "homosexuality is a curse and that God should punish those who are engaged in the act, just as God reacted to the people of Sodom and Gomorrah."20 John Ernest continues that "Africa has no right to respect gays according to African tradition and even the Bible. In fact, the act of gay is immoral and should be condemned by all civilized nations of the world." ${ }^{21}$ Yet there are those who feel that Africa would be throwing away its culture and ethics to the Western culture and principles and thus playing the fool if it should respect the right of the homosexuals. That is why there has been a strong reaction to the gay activist group's effort to stall a bill seeking to ban same sex marriages in Nigeria. ${ }^{22}$

Though there has been a few dissenting voices, the general consensus in the African milieu is that homosexuality should not be allowed to take root in Africa. It is foreign to African culture and religion. Thus, its manifestation should be treated as an aberration rather than a socially acceptable behavioural pattern. But is this in line with how traditional Africans viewed it? Ebun Oduwole, an erudite of great influence on traditional African bioethics disaffirms. This is a view some other minds such as Laurent
Magesa, Placid Tempels may also share with Oduwole.

In spite of her admission that there were instances of homosexual and inter-sex persons among the traditional Yoruba, Ebun Oduwole argues that it was generally frowned upon. In her words, Oduwole affirms:

"...Homosexuality is not as alien to traditional African societies as some people would want us to believe. However, it is equally clear that while there were traces of the phenomenon in indigenous Yoruba society, for example, it was generally considered to be unacceptable. Hence, the Same-Sex Marriage Prohibition Act of 2014 in Nigeria is consistent with our cultural values" (emphasis mine). ${ }^{23}$

Oduwole makes two seemingly valid but erroneous claims in the above. I will summarily tend to these as I simultaneously pull the erroneous and misleading implications of her rendition.

Her evidence that homosexuality "...was generally considered to be unacceptable..."24, in indigenous Yorùbá society derives from Ódù Otúrá Gorì-ìrete, one of the many verses of the Ifá corpus whose rendition in the English is thus:

Two men are copulating Two men are copulating Two women are copulating, two women are mating 
Why don't we take a man?

And then take a woman

Why don't we take a man?

And then take a woman

Therein lies enjoyment and

fulfilment

Divination was cast for

Erifobogbile

The (Primordial) Head's

diviner divined for it too

When head was to site a

domicile

Head was told to offer a

sacrifice

May I trade and make profits

My (primordial) head, may I

have two thousand children

May I trade and make profits

Oduwole is assured that this Ódù "gives a vivid account of homosexuality and points to it as an exercise in futility." ${ }^{25}$ However, it is strange how her perception that homosexual affair is an exercise in futility is

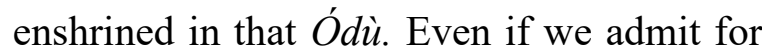
the sake of argument, Oduwole's conviction that homosexuality is an exercise in futility perhaps because procreation does not ensue, then Oduwole must be willing to shun heterosexual women with Mullerian agenesis from sexual intercourse since that too will be an exercise in futility. Medically certified barren women and women past menopause who are heterosexuals, will on the showing of Oduwole be performing exercises in futility. Her reasoning may even imply that they need not make love again. In retrospection, Oduwole may say that the Ódù reveals that a man-woman sexual intercourse is more enjoyable and fulfilling than a homosexual intercourse. She may use the Yorùbá saying that "His eyes are like the eyes of one who has anal sex" to justify this seeming lack of enjoyment. However, this reasoning too is flawed. As a result, Homosexuals engaged in anal sex have not come out to say that they lack enjoyment and fulfillment. To feed this proposition into their sexual orientation and then criticize same clearly indicates the Strawman Fallacy. Analogically, there are reported cases of vaginal intercourse where the woman complains of discomfort and pains, sometimes accompanied with bleeding. Whither pleasure and fulfillment? Obviously, enjoyment and fulfillment in sexual intercourse is an argument that may be deployed to both homosexuals and heterosexuals. It is not a yardstick to relegate or denounce the former and be mute regarding the latter. I find recourse to the Ifá corpus as a basis for the rejection of homosexual practices in traditional Yorùbá societies as inefficient. I will amplify this position in the next section. For the moment, I concern with Oduwole's second erroneous and misleading claim.

Oduwole stresses that "the Same-Sex Marriage Prohibition Act of 2014 in Nigeria is consistent with our cultural values."26 Here, she assumes that Nigeria is a homogenous political entity, where what holds in a predominantly Christian South 
with diverse ethnic groups obtains in a predominantly Muslim North where the Sharia operates. Moreover, I beg to differ from Oduwole to show that the Same-Sex Marriage Prohibition Act of 2014 is not consistent with African cultural values. Some instance will suffice here!

Among the traditional Hausa in present day Northern Nigeria and the Lango people of Northern Uganda, there were men identified as yan duada and makudo dako respectively. In the words of Mathew Paige yan duada "... were effeminate men and were considered an option for other men to marry. Other traditions were found in the Nilotico Lango. There was the third gender makudo dako, which were people of the male sex who dressed as women, and treated as women. Marriage between men and makudo dako was a common practice." ${ }^{27}$ Similarly, among the traditional Yorùbá the terms adofùrọ and lakíriboto, are suggestive of gay and inter-sex persons respectively. There were no strict penal codes against these humans. They were respected and accorded their own rights as human beings. There were neither Sharia laws that made them death row candidates nor imprisonments of a decade and four years. To then insist as Oduwole does that that "Same-Sex Marriage Prohibition Act of 2014 in Nigeria is consistent with our cultural values" 28 is not anywhere close to the truth, unless of course she means our cultural values diluted with Euro-Christian and Arab-Islamic orientations. At this juncture, a critic may demand whether or not dressing is a sufficient determinant of the nature of humans to be classified into the popular binary sexual orientation of malefemale. This study ripostes that this may be necessary; it is not a sufficient condition. There are many straight males who dress as female just as gay males persist and dress like females. Dressing is not a sufficient yardstick granted that it is necessary to differentiate the two popular sexes.

Thus far, I have been able to establish two crucial aims here. The first is that the African heads of government who tinker that homosexuality was alien to Africa are not enlightened enough regarding Africa's history of sexuality. The second is the erroneous rendition by Oduwole and her disciples that in spite of the traces of homosexual, the reality was perceived as a threat to heterosexual marital institutions and procreation.

Personally, I find these outlooks premised on the lack of proper scientific basis for homosexuality. In the remainder of this inquiry, I seek to unclad a more plausible trado-Yorùbá explanation for the existence and persistence of homosexuality among humans and why these persons were not discriminated against back then.

The Trado-Yorùbá Discourse on the Efficient Causation of Homosexual Persons: In this section, I offer a causative explanation for homosexuality using Yorùbá 
myth as cue. However before disclosing this affair, it is important to offer that homosexual behaviours have received minimal causal explanation vis-à-vis realities like kleptomaniac. Whereas the kleptomaniac has an inherent genetic disposition to acquire by crook, what does not belong to them, the homosexual is on the defensive. The latter has no genetic explanation from research authorities of the mainstream and dominant scientific enterprise and also face stigmatization and persecution more than the kleptomaniac. The question there is: how have traditional Africans engaged and speculated on homosexuality, I use the traditional Yorùbá folklore as a cue.

Before the advent of colonialism and the enchanted of the African mind with Arabic and Western values, cultures and religions, there were allegories used to explain why things are the way that they are. These allegories or myths have served as a way of understanding the world, for social cohesion and mutual coexistence. A critique may at this junction refuse to bat an eye, over my choice for myths as a basis even when it is the case that had already ceded that there is no scientific consensus on homosexuality. Hence, I need to provide an explanatory justification before exploring the indigenous Yorùbá creation myth as a plausible reason why there were no homophobic acts in precolonial times. While speaking on the role that myths play in the development of scientific theories, renowned erudite Sir Karl Raimund Popper leaks:

"I realize that such myths may be developed, and become testable; that historically speaking all - or very nearly all - scientific theories originate from myths and that a myth may contain important anticipations of scientific theories. Examples are Empedocles' theory of evolution by trial and error or Parmenides' myth of the unchanging block universe, in which nothing ever happens and which if we add another dimension becomes Einstein's block universe..." 29

Obviously, several factors militating against the development of African Science will have made the development of African myths into testable scientific theories impossible. Factors as poor understanding or complete ignorance of indigenous cultures and tradition, the aftermath of Arab-Islamic and Euro-Christian values, education, religions, culture and traditions are foremost. But my contention is not to engage with these. My point is that the Yorùbá creation myth is pregnant with some testable truths which render homophobic ideas obsolete. I will now concern with the myth of the creation of humans as holds among the traditional Yorùbá.

If there is any truth in the role that sexual selection play in reproduction, it is minimal. This claim is incontestable if one recalls that there are several cases of sexual relations that do not yield into conception, pregnancy, 
gestation and then finally delivery. In the words of Olanrewaju Shitta-Bey "it is a scientific fact that sexual intercourse does not necessarily result into pregnancy even when the spermatozoa of a man and the ovum of his female counterpart are medically proven to be satisfactorily active." 30 It is therefore not uncommon to have many sterile personalities among species in the plant and animal kingdoms. Contrary to the claim of Charles Darwin ${ }^{31}$, the traditional Yorùbá contests that sexual selection plays minimal role as the impact of other factors have not been take into consideration. In plain language, sexual intercourse as an aftermath of the evolutionary theory of sexual selection does not guarantee reproduction and ultimately the preservation of the species. If the Yorùbá evolutionary theory and the role of Olódùmarè (Higher God) and the òrișàs (divinities) are used to assess this reality, it becomes clear that even traditional Yorùbá has more consistency over Darwin's theory of evolution through natural and sexual selection. At this juncture, a re-interpretation is needed to for the Yorùbá human creation account in order to put in the proper perspective, the role of Olódùmarè and the òrișàs in the affairs of the universe.

It is not to be contested that the saying: "Olódùmarè ní ó n fún énìyàn ni omo" (Olódùmarè, the Higher God is the giver of children) is permeating among the traditional Yorùbá. It is this additional condition that the traditional Yorùbá adds to the role of natural and sexual selection. This condition is the role played by Olódumarè and the òrișàs during and after sexual intercourse. It is from this truth that when Olódùmarè and the òrişàs bless the union of a man's sperm cell and a woman's egg cell after sexual intercourse or manipulation over a petri dish (if it is a biotechnological process), that the Yorùbá may utter: "O $\mathrm{ti}$ ferakü" (Conception has occurred in her/it). This is seen by the Yorùbá as a sign that Olódùmarè and the òriṣàs have granted their request toward procreation. One point must be noted here though! There is a large gulf between "O ti ferakù" (Conception has occurred in her/it) and "O ti l'oyun" (Pregnancy has occurred in her/it) for the traditional Yorùbá. This is "because the stages/processes involved between the moment of conception and the delivery of the baby (for instance, Orisha Nla may or may not carry the function of molding the Ara of the human person)" $" 32$ A proper and detailed account of the evolution of the foetus has been documented by Olanrewaju Shitta-bey. I will not pursue that case further to avoid digression from the aim of this research. Hence, I concern with the primordial deity called Orișànlá. Who is Orișàńlá? How important is this entity toward the creation of a human?

It is agreed that Obàtálá or Oriṣàńlá (one of the primordial divinities in the Yorùbá world-view (fond of drinking palm wine) fashions a human body (ara) out of clay or sand. Meanwhile, Olódùmarè (Higher God) 
gives life-force or soul (Èmi) to the 'craft' of Orișànlá. The animated ara then proceeds to Ajàlá's abode (another primordial divinity who makes $O r i$ ) to make a choice of destiny, Orí.

Granted, Orișàńlá is the primordial divinity that casts a human body, it is very likely that he may cast inter-sex persons. He may omit the genitals of a woman, thereby creating confusion of the sex of the person. ${ }^{33}$ Assuming a critic interposes at this juncture that Oriṣànlá has the capacity to cast a kleptomaniac. Would this not justify the stealing on the part of the human entity? On first showing, this observation is correct. A deeper reflection will however reveal to the critic that the condition of the kleptomaniac has genetic and scientific explanations. Homosexuality is however futile in explanation, hence the recourse to traditional Yorùbá folklore. Secondly, there are no recorded cases of kleptomaniac among traditional and even the contemporary Yorùbá. Such an act as kleptomaniac has no existence in the history and tradition of the people. It will therefore be a form of conceptual superimposition on the part of the critic, demanding that kleptomaniac be given causal validation as homosexuality from Yorùbá folklore.

Extemporaneously, “Òriṣàńlá could mould a woman with stronger bones and muscles that will make her more masculine. He may also mould women without womb."34 Furthermore, and in the most severe cases, he "may not carry the function of molding the ara of the human person," 35 and this could lead to miscarriage for the gestating woman. These are perhaps some of the ideas that inform the traditional Yorùbá position on sexuality. It therefore does not strike one that traditional Yorùbá sexuality is one that recognizes that aside the male and female sexes, there could be other sexes that emanate from the craft of Orișànlá. This is precisely why in the Yorùbá language, there is not gender-specific pronoun for the male and female sexes. ${ }^{36}$ In addition, "Biological anatomy is not a limitation to social status as that of husband, wives, mothers, or fathers among the Yoruba. In addition, the Yoruba language provides no pronoun for sexual distinction. The notion of gender among the Yoruba is complex and multidimensional."37 The climax of this study have served to reveal that among the indigenous Yorùbá, there is a likely understanding of homosexual and inter-sex persons as the crafts of Oriṣànlá, in a similar way that albinos too. There was no jail terms for these peoples neither were they restricted from social life. Clearly, traditional Yorùbá society is not a homophobic one. It was a kind of society where sex and gender are flexible and amenable.

Some Recommendations: In the light of the arguments that I have put forward in the last section, it is the case that there is an established but unfair exposition by scholars regarding ancient Yorùbá explanation for the cause of homosexuality and the general 
acceptance back then. Hence, it is the recommendation of the study that since homosexuality was not frowned upon by African progenitors it is fallacious, to put this as a justification for the criminalization of homosexuals. It is for this reason that I propose for the repeal of the Same-Sex Marriage Prohibition Act of 2014, which is not consistent with African cultural values. Hence, similar laws in other parts of Africa should similarly be repealed.

Thirdly, there is need for sexuality orientation for people who discriminate against homosexuals in social and work places. Information centers should be made available for citizens to get adequate resources on what homosexuality is about. Furthermore, they must be made to realize that the causative factor through the teaching of traditional African folklores. Here, schools should educate young people especially about it such that it does not come strange as they get older.

Conclusion: This essay has explored the characterization and extent of three claims on homosexuality. First, that there is no scientific consensus regarding the cause of homosexuality. That there is no scientific evidence for homosexuality does not strengthen the case of most African leaders who condemn the reality. 'Western' science does not have the final answer to all things. These leaders are therefore left with the option of perusing indigenous African cultures for answers. It is however the case that the influence wielded by Christianity
In addition to the foregoing, homosexual persons who have contributed to the development of the society through their efforts in various spheres of life should be celebrated and not be discriminated against. Through this, homosexuals may be seen beyond their sexuality but just like any other human.

and Islam over the minds of contemporary African leaders is an impasse to the natural admission of homosexuality among the African forbearers. Second, that African leaders and scholars who have upheld the anti-same sex marriage either understanding of African culture or are just homophobes who do not wish to have any interaction with homosexuals. These persons have also used the glorious past of Africa to gird their resolve that homosexuality is un-African. Third, that the traditional Yorùbá community like many other pre-colonial areas in Africa was not against homosexuals since there is no evidence revealing that homosexuals were punished, discriminated and persecuted as they are in recent times. Impliedly, my contention is that homosexuality is not foreign to Africa and for the traditional Yorùbá, it is Orisàńlá that stands as efficient cause for their being. It is therefore the recommendation of this work to revive this idea that it is Orișànlá that made the homosexual thus. Unless we do this, there is clear evidence that we in the $21^{\text {st }}$ century are vicious but not virtuous, 
lettered but not fully educated, in our dealings with 'fellow humans' whose places we may be, had Òiṣàńlá taken an overdose of his favourite, the palm wine. Homosexuality by its very nature is neither a vice nor a virtue. It is a reality that relies on the context. The serial rapist, kleptomaniac, racists are deemed virtuous or otherwise within contexts and the science of their conditions. The kleptomaniac is clinically validated and the judge will be lenient. A serial rapist may in very rare cases get leniency since he could be medically validated to have mental disorders vis-à-vis the 'one-off-rapist.' Bias as to what constitute rape and mental state may also come to play. However, the homosexual is bogged down by prejudices and perceived as a threat to family values irrespective of context. Homosexuality is neither virtue nor vice. It needs to be contextualized before this disjunction can work. Strictly speaking

\section{References:}

${ }^{1}$ K.A. Rodier. "Biologism and Simone de Beauvoir: A Phenomenological Re-Reading of "The Givens of Biology"'. M.Phil Thesis Submitted to Department of Philosophy, University of Sasketchewan, Saskatoon, Canada 2007 , p. 10

${ }^{2}$ See Natalie Angier. "Study Suggests Genes Sway Lesbian's Sexual Orientation". New York Times. March 1993a 12; Natalie Angier. "Report Suggests Homosexuality is Linked to Genes". New York Times. July 1993b, 16.

${ }^{3}$ Christopher Daly. "Study of Twins Suggest Lesbianism has a Genetic Component". Washington Post. March 199315.

${ }^{4}$ Curt Suplee. "Study Provides New Evidence of "Gay Gene"”. Washington Post. October 1995 31

${ }^{5}$ Stanton L. Jones and Don E. Workman. "Homosexuality: The Behavioural Sciences and the whole gamut of this inquiry has been dedicated to this.

Author Contribution: Author developed the conceptual idea and wrote the manuscript.

Conflict of Interest: Declared none.

Acknowledgements: I wish to acknowledge the intellectual exploration of bioethics within the African purview as laid out in the reflections of Professor Ebun Oduwole, one of the prominent sages of the Ogun School of Philosophy, Olabisi Onabanjo University, Ago-Iwoye, Nigeria. More so, I desire to use this medium to relay my profound gratitude to a former student, Emmanuel Ofuasia whose critical comments, conceptual clarifications and accentuation on clarity of arguments has added value to this research. I thank him immensely.

the Church". Journal of Psychology and Theology. 1989213.

${ }^{6}$ Richard C. Friedman and Jenifer Downey. Sexual Orientation and Psychoanalysis: Sexual Science and Clinical Practice. (New York: Columbia University Press 2002)

${ }^{7}$ L.D. Wardle. "The Biological Causes and Consequences of Homosexual Behavioural and Their Relevance for Family Law Policies". DePaul Law Review. 56(3): 997-1034

${ }^{8}$ Op. Cit., Friedman and Downey, p. 39

${ }^{9}$ Simon LeVay . "A Difference in Hypothalamic Structure between Heteroseuxal and Homosexual Men". SCIENCE. 19911034.

${ }^{10}$ William Byne and Bruce Parsons. "Human Sexual Orientations: The Biological Theories Reappraised". Archives of General Psychiatry 1993228. 
${ }^{11}$ Simon Burton. The Causes of Homosexuality: What Science Tells Us. (Cambridge: Jubilee Centre 2006)

${ }^{12}$ Michael Yudell. "A Short History of the Concept of Race.” In S. Krimsky \& J. Sloan (eds). Race and Genetic Revolution: Science, Myth and Culture. Pp. 13-30. (New York: Columbia University Press 2011), p. 22

${ }^{13}$ Rick Wiess \& Justin Gillis. "Teams Finish Mapping Human DNA." Washington Post. 2000

${ }^{14}$ F.S. Collins, M.K. Mansoura. "The Human Genome Project: Revealing the Shared Inheritance of all Humankind." Cancer. 2001, Vol. 92, p. S224

${ }^{15}$ Op. Cit., Kahn-Fogel, p. 316

${ }^{16} \mathrm{~K}$. Boykin "Homosexuality in Africa." http://www.keithboykin.com/author/ africa.html. Posted January 11, 2001. Retrieved on the 11th April, 2018.

${ }^{17}$ John Ernst. "BBC Africa Live". http://www.mask.org.za/article.php?cat=ajd=74. Retrieved on the 15th August, 2018.

${ }^{18}$ Op Cit., Boykin

${ }^{19}$ Op Cit., Obasola, p. 84

${ }^{20} \mathrm{Op}$ Cit., Ernst

${ }^{21}$ Ibid

${ }^{22}$ Op. Cit., Obasola, p. 83

${ }^{23}$ Ebun Oduwole. Philosophy and the Challenge of Relevance in African Society. $79^{\text {th }}$ Inaugural Lecture. Olabisi Onabanjo University, AgoIwoye, Ogun State. $20^{\text {th }}$ February, 2018., p. 15

${ }^{24}$ Ibid, p. 15

${ }^{25}$ Ibid., p. 14

${ }^{26}$ Ibid., p. 15

${ }^{27}$ Op. Cit., Paige

${ }^{28}$ Op. Cit., Oduwole, p. 15

${ }^{29}$ Karl R. Popper. Conjectures and Refutations. (London: Routledge \& Kegan Paul 1963), p. 36

${ }^{30}$ Olanrewaju. A Shitta-Bey. "The Humanity of the Foetus: A Yorùbá Perspective." African Journal of History and Culture. 20157 (2), p. 54

${ }^{31}$ Charles Darwin. On the Origin of Species by means of Natural Selection, or the Preservation of Favoured Species in the Struggle for Life. (New York: Modern Library Edition 1949).

${ }^{32}$ Op. Cit., Shitta-Bey, p. 54

${ }^{33}$ Babajide Olugbenga Dasaolu. "Òrìșànlá made me thus: Arguing for Homosexuality using the
Yorùbá Thought System as Paradigm." LASU

Journal of Philosophy. 2018 Vol. 1 (2), p. 201

${ }^{34}$ Ibid, p. 201

${ }^{35}$ op. cit, Shitta Bey p. 54

${ }^{36}$ See O. Oyewunmi. The Invention of Women: Making an African Sense of Western Gender Discourses. (Minneapolis: University of Minnesota Press 1997)

${ }^{37}$ O. Olajubu. "Seeing Through a Woman's Eye: Yorùbá Religious Tradition and Gender Relations." Journal of Feminist Studies in Religion. 200420 (1), p. 42 